\title{
Cohort Study: The Accuracy of Screening Methods of COVID-19 in Pregnancy: Practical Approach in Low Resources Health Services
}

Muhammad Ilham Aldika Akbar ${ }^{1}$, Khanisyah Erza Gumilar ${ }^{1}$, Eccita Rahestyningtyas ${ }^{1}$, Manggala Pasca Wardhana ${ }^{1,2}$, Pungky Mulawardhana ${ }^{1}$, Jimmy Yanuar Anas ${ }^{1,2}$, Ernawati ${ }^{1,2}$, Muhammad Ardian Cahya Laksana ${ }^{1}$, Hermanto Tri Joewono ${ }^{1}$

${ }^{1}$ Department Obstetrics \& Gynaecology, Faculty of Medicine Universitas Airlangga Universitas Airlangga Academic Hospital

${ }^{2}$ Department Obstetrics \& Gynaecology, Faculty of Medicine Dr. Soetomo General Academic Hospital

\section{Institutions}

Faculty of Medicine Universitas Airlangga

Kampus A UNAIR, Jl. Mayjen Prof. Dr. Moestopo No. 47, Surabaya, Indonesia $+620315020251$

\section{Universitas Airlangga Hospital}

Jl. Dharmahusada Permai, Mulyorejo, Kec. Mulyorejo, Kota SBY, Jawa Timur 60115, Surabaya, Indonesia

$+6203158208283$ 
medRxiv preprint doi: https://doi.org/10.1101/2021.09.20.21263866; this version posted September 26, 2021. The copyright holder for this preprint (which was not certified by peer review) is the author/funder, who has granted medRxiv a license to display the preprint in

\section{Corresponding Author}

Muhammad Ilham Aldika Akbar, PhD, MD

Department Obstetrics and Gynecology Faculty of Medicine Universitas Airlangga, Indonesia

- Universitas Airlangga Hospital

email: muhammad-i-a-a@fk.unair.ac.id or dokter_aldi@yahoo.com

\section{Abstract \\ Background}

All pregnant women in labor should be universally screened for Coronavirus Disease 2019 (COVID-19) during pandemic periods using Reverse Transcriptase Polymerase Chain Reaction (RT-PCR) test. In many low-middle income countries, screening method was developed as an initial examination because of limited availability of RT-PCR tests.

\section{Objectives}

This study aims to evaluate the screening methods of COVID-19 accuracy in pregnant women.

\section{Material and Methods}

We recruited all pregnant women with suspicion of COVID-19 from April - August 2020 at Universitas Airlangga hospital, Surabaya, Indonesia. The participant was divided into two groups based on RT-PCR results: COVID-19 and non-COVID-19 group. The proportion of positive signs \& symptoms, rapid antibody test, abnormal findings in chest x-ray, and neutrophil to lymphocyte ratio (NLR) value were then compared between both groups. The sensitivity, specificity, positive predictive value (PPV), negative predictive values (NPV), and diagnostic accuracy (DOR) were calculated.

\section{Results}

A total 141 pregnant women with suspected COVID-19 cases were recruited for this study. This consist of 62 COVID-19 cases (43.9\%) and 79 non COVID-19 pregnant women $(56.1 \%)$. 
medRxiv preprint doi: https://doi.org/10.1101/2021.09.20.21263866; this version posted September $26,2021$. The copyright holder for this preprint (which was not certified by peer review) is the author/funder, who has granted medRxiv a license to display the preprint in

It is made available under a CC-BY-NC-ND 4.0 International license.

The sensitivity, spesificity, PPV, NPV, and diagnostic accuracy of each parameter are as follow: clinical sign \& symptoms $(24.19 \%, 75.95 \%, 3.92 \%, 96.11 \%, 65.87 \%)$, rapid antibody test $(72.73 \%, 35.06 \%, 4.35 \%, 96.94 \%, 36.53 \%)$, chest $x$-ray $(40.68 \%, 59.45 \%, 3.92 \%, 96.11 \%$, $58.76 \%)$, and NLR $>5.8(41.38 \%, 72 \%, 5.66 \%, 96.80 \%, 70.81 \%)$.

\section{Conclusions}

The use of combined screening methods can classify pregnant women with high-risk COVID19 before definitively diagnosed with RT-PCR. This practice will help to reduce RT-PCR need in a limited resources country.

\section{Keywords}

COVID-19, Pregnancy, Screening, Diagnosis

\section{Introduction}

From the start of March 2020 until now (January 12th, 2021), the Coronavirus Disease 2019 (COVID-19) pandemic has infected 91.314.370 peoples worldwide and lead to 1.952 .879 total death (1). Indonesia has become one of the most important spreading centers in South Asia, especially Southeast Asia. Until now (January 12th, 2021), there has been a total of 828.000 COVID-19 cases in Indonesia, with total death of 24.129 peoples (Case Fatality Rate [CFR] 2.91\%) (2). COVID-19 pandemic also has a significant impact on pregnancy, which is the increased maternal morbidity and mortality. Pregnancy with COVID-19 poses specific challenges because most of the cases were asymptomatic. A study performed at Universitas Airlangga Hospital found $75.8 \%$ of pregnancies with confirmed COVID-19 have no signs or symptoms. This finding is in line with the New York study, which found $87.9 \%$ of pregnant women with COVID-19 also asymptomatic (3). It is essential to determine the COVID-19 status of pregnant or delivering women because confirmed cases need unique and more 
medRxiv preprint doi: https://doi.org/10.1101/2021.09.20.21263866; this version posted September 26, 2021. The copyright holder for this preprint (which was not certified by peer review) is the author/funder, who has granted medRxiv a license to display the preprint in It is made available under a CC-BY-NC-ND 4.0 International license .

comprehensive management. Many international guidelines from Obstetrics \& Gynaecologic organization recommend universal screening of COVID-19 for women in labor during this pandemic period (4-9). In the developed countries with adequate resources, universal screening of COVID-19 is performed using a gold standard: Reverse Transcriptase Polymerase Chain Reaction (RT-PCR) from the oropharynx and nasopharyngeal swab samples.

However, in low-middle income countries without sufficient resources and limited RTPCR availability for diagnostic, such practice is difficult to perform. Therefore some modification was made to overcome this problem. The golden standard of RT-PCR is only performed in a case with a high suspicion of COVID-19 (high-risk group). Initial classification of a patient is performed using combined screening methods, including sign \& symptoms, physical examination, laboratory result, radiology examination (Chest CT-scan, Chest X-ray), and serological test (rapid test antibody). The clinical manifestation of COVID-19 includes fever, cough, dyspnea, myalgia, sore throat, anosmia, ageusia, dan nausea vomiting (10-12). These symptoms become the most basic screening methods for all women in labor. The laboratory examination usually shows a sign of lymphocytopenia, increased C-reactive protein (CRP), leukocytosis, lymphopenia, neutrophilia, and increased neutrophil/lymphocyte ratio (NLR) $(13,14)$. Predominant findings of peripheral airspace shadowing and bilateral, multilobar ground-glass opacities or consolidation in the chest x-ray or chest CT indicating a suspicion of COVID-19 infection. (15). A serological test in low-middle income countries is used as a additional test to diagnose Coronavirus disease, besides the ideal molecular viral test. The advantages of rapid antibody tests include easy to perform, cheap, and does not need a complete facility or trained examiner compare to the RT-PCR examination (16). Considering the limited availability of diagnostic RT-PCR of COVID-19 in many hospitals, we conduct a study to assess screening methods' diagnostic accuracy in pregnancy. 
medRxiv preprint doi: https://doi.org/10.1101/2021.09.20.21263866; this version posted September $26,2021$. The copyright holder for this preprint (which was not certified by peer review) is the author/funder, who has granted medRxiv a license to display the preprint in It is made available under a CC-BY-NC-ND 4.0 International license.

This study evaluates the diagnostic accuracy of screening methods of COVID-19 on pregnancy by comparing it with the RT-PCR as the gold standard.

\section{Material and Methods}

This study is part of a cohort study of suspected COVID-19 cases in pregnant women in Universitas Airlangga Hospital (Surabaya, Indonesia) from April - August 2020. This study aims to evaluate the accuracy of our screening methods of COVID-19 in pregnant women. We performed a universal screening COVID-19 in pregnant women in labor based on our original screening methods: which is the presence of one of the clinical sign-symptoms of covid 19 (fever, cough, dyspnea, sore throat, myalgia, or nausea vomiting) or the positive rapid antibody covid-19 test, or the chest x-ray findings, or the abnormality of complete blood count (CBC) especially NLR $>5.8$ (Figure 1). The inclusion criteria of this study is all pregnant women suspected of COVID-19 (based on our screening methods) that delivered in Universitas Airlangga hospital during study periods. There is no spesific exclusion criteria in this study. All participant were recruited for this study following informed consent. The final diagnosis of all subjects was then confirmed with the RT-PCR. The sample was taken from the nasopharyngeal and oropharyngeal swabs. The subject was divided into two groups based on the RT-PCR result as non-covid or covid groups.

The study's primary outcomes were the diagnostic accuracy of the clinical sign, rapid antibody test, chest x-ray, NLR, and the combined clinical sign compared to the RT-PCR result. The combined clinical sign was defined as a presence of minimal one suspicious sign and symptoms of COVID-19. The presence of peripheral airspace shadowing and bilateral multilobular ground-glass opacities in chest $\mathrm{x}$-ray was considered a suspicious sign of COVID19. Rapid antibody test was performed using "One Step Rapid Test" - SARS-CoV-2 IgM/IgG 
medRxiv preprint doi: https://doi.org/10.1101/2021.09.20.21263866; this version posted September $26,2021$. The copyright holder for this preprint (which was not certified by peer review) is the author/funder, who has granted medRxiv a license to display the preprint in It is made available under a CC-BY-NC-ND 4.0 International license .

Ab Rapid Test Kit (Qingdao Hightop Biotech Co., LTD). This test is used to detect the IgM and IgG antibodies to SARS-CoV 2 in human serum, plasma, or whole blood. The sensitivity and specificity of this test claimed by the company: $\operatorname{IgM}(83 \%$ \& 97\%) and $\operatorname{IgG}(93 \%$ \& $97.5 \%)$ (17). Peripheral blood NLR (Neutrophil/Lymphocyte Ratio) has been shown by many studies as a good marker of systemic inflammation, likewise in COVID-19 infection (18). NLR was count by dividing Neutrophil count with Lymphocyte count from the Complete Blood Count examination. We used a cut-off value of NLR $>5.8$ as a screening method of COVID-19.

\section{Ethical Consideration}

This study has been approved by the Research Ethics Committee of Universitas Airlangga Hospital (Ref. No: 110/KEP/2021). All participant has understand the information of consent of this study including the objective, protocol, risk, and anonimity. All participant has signed the informed consent form before involved in the study.

\section{Statistical Analysis}

The data was analyzed using IBM ${ }^{@}$ SPSS $^{\odot}$ Statistics ver 25. Descriptive statistics was used first to determine the distribution normality of the numerical variables. The numerical variables with a normal distribution (hemoglobin, leucocytes, thrombocyte) were analyzed using an independent t-test value (table 1). The numerical variables with abnormal distribution (Neutrophil, Lymphocyte, NLR) was applied to the Mann Whitney test (table 1). A Chi-Square/ Fischer's exact test was used to analyze the difference between categorical variables (table 1). Significant value is defined as p-value $<0.05$. To evaluate the diagnostic accuracy of all the variables we measured: the sensitivity, specificity, positive likelihood ratio (PLR), negative likelihood ratio (NLR*), positive predictive value (PPV), negative predictive value (NPV), and overall accuracy (table 2). 
medRxiv preprint doi: https://doi.org/10.1101/2021.09.20.21263866; this version posted September 26, 2021. The copyright holder for this preprint (which was not certified by peer review) is the author/funder, who has granted medRxiv a license to display the preprint in It is made available under a CC-BY-NC-ND 4.0 International license .

\section{Result}

A total of 141 suspected covid-19 cases in pregnancy were recruited during this study period. Sixty-two subjects were confirmed as COVID-19 cases (43.9\%) and seventy-nine subjects as non-COVID-19 cases (56.1\%). The summary of screening and diagnostic results between both groups can be seen in table 1 . The presence of combined signs and symptoms did not differ between both groups. We also compared and analyzed each sign \& symptoms individually between both groups (cough, fever, dyspnea, sore throat, myalgia, and nausea vomiting) and found no significant differences. The rapid antibody test once again fails to show any difference between both groups. $2,5 \%$ and $11.3 \%$ of patients from non-covid-19 and covid19 groups did not have a rapid antibody test examined. Furthermore, the abnormalities of chest X-ray and NLR $>5.8$ is not different between both groups. Additionally, the complete blood count (hemoglobin, leucocyte, thrombocyte, neutrophil, lymphocyte, and NLR) mean/median value is not significantly different between these two groups.

The diagnostic accuracy of the clinical sign-symptoms, laboratory test, rapid antibody covid-19 test, and a chest x-ray was further analyzed (Table 2). Rapid antibody test has the highest sensitivity compared to other modalities $(72.73 \%)$, while on the contrary, sore throat has the lowest one (4.84\%). The clinical manifestation of nausea, vomiting, sore throat, fever, and dyspnea have the highest specificity compared to other examinations $(97.47 \%, 94.94 \%$, 93.67\%, and 92.41\%). The highest PLR was found in the existence of fever (2.29). On the other hand, the highest NLR was found in cough, sore throat, combined sign-symptoms, and chest Xray (1.00-1.01). The presence of nausea, vomiting, and fever has the highest positive predictive value $(9.37 \%$ and $8.52 \%)$, although the actual value is deficient. This finding was in contrast with the negative predictive value measurement, which showed a relatively high percentage in all screening-diagnostic modalities $(96.0-96.9 \%)$. The overall diagnostic accuracy of these 
medRxiv preprint doi: https://doi.org/10.1101/2021.09.20.21263866; this version posted September 26, 2021. The copyright holder for this preprint (which was not certified by peer review) is the author/funder, who has granted medRxiv a license to display the preprint in

It is made available under a CC-BY-NC-ND 4.0 International license .

modalities was varied (36.53-93.92), with the highest one include nausea, vomiting $(93.92 \%)$, sore throat $(91.42 \%)$, and fever $(90.58 \%)$. We analyze the NLR value's ROC curve to predict COVID-19 infection in pregnant women (figure 2), and the Area Under Curve (AUC) value is 0.561. With the cut-off value that we used (5.8), the sensitivity and specificity from the ROC curve were only $37.9 \%$ and $30.7 \%$.

\section{Discussion}

This study point that the screening methods of COVID-19 have various diagnostic accuracy (DOR: 36.53-93.92). The presence of individual signs and symptoms has the highest diagnostic accuracy (with the order: nausea, vomiting, sore throat, fever, dyspnea, and cough) followed by NLR, chest x-ray, and serological test. However, the diagnostic accuracy of combined sign and symptoms occupy the second rank after NLR. In pregnancy, this becomes a problem since most pregnant women with COVID-19 have no clinical symptoms $(3,19,20)$. A meta-analysis study including 96.604 participants compared pregnant women with and without COVID-19 infection from the universal screening, show that three-quarter of 162 infected pregnant women was asymptomatic (74\% from 11 studies) (21). A similar result is also found in this study: $75 \%$ of pregnant women with COVID-19 has no symptoms when admitted to the hospital. The most significant and symptoms found in this study are cough, fever, and dyspnea, in line with many studies (21-26). Unfortunately, in this study, we did not evaluate anosmia and ageusia symptoms, which were later known as an essential clinical sign of SARS-CoV-2 infection (27). The combined clinical symptoms, in general not appear to be an adequate screening method, considering the low sensitivity (24.19\%) and PPV (3.92\%).

On the other hand, clinical symptoms have a reasonable specificity and NPV: the specificity for individual symptoms: $>75 \%$, for combined symptoms: $>90 \%$, and NPV $>96 \%$. In other 
medRxiv preprint doi: https://doi.org/10.1101/2021.09.20.21263866; this version posted September 26, 2021. The copyright holder for this preprint (which was not certified by peer review) is the author/funder, who has granted medRxiv a license to display the preprint in It is made available under a CC-BY-NC-ND 4.0 International license.

words, the combined clinical sign and symptoms have a low false-positive rate for diagnosing the SARS-CoV-2 infection. So that in pregnant women with high suspicion of COVID-19 infection, if we found one of the clinical symptoms, it is most likely infected with SARS-CoV2. In general, the presence of one symptom has a moderate diagnostic accuracy (DOR: 65.87). This study indicates that clinicians can utilize the sign and symptoms to rule in pregnant women with suspicion of COVID-19.

The finding of infiltrate on chest $\mathrm{x}$-ray in this study shows a moderate diagnostic accuracy of COVID-19 in pregnant women. CT chest is usually preferred in diagnostic of COVID-19 compared to a chest x-ray. Many guidelines recommend using CT chest as a primary diagnostic tool in pregnant women with suspicion of COVID-19 in a high endemic area (28). Chest CT has known to have a high sensitivity to diagnose COVID-19 (29). Unfortunately, in low-middle income countries, the chest CT is often unavailable; therefore, a chest x-ray can be utilized as an alternative substitute. This study shows a moderate result of sensitivity, specificity, and NPV of a chest x-ray to diagnose COVID-19 infection (40.68\%, $59.45 \%$ dan $96.11 \%$ ). This method can be used as an early screening method in pregnant women with suspicion of COVID-19. A study from India reports the use of artificial intelligence assisted chest x-ray examination to increase the detection accuracy of COVID-19 (90.5\% with sensitivity $100 \%$ ) (30). These findings will be beneficial in countries with limited resources to increase the screening and detection of COVID-19 by using chest x-ray in highrisk pregnant women. Therefore our national Obgyn society (POGI) has released an official recommendation to use chest $\mathrm{x}$-ray as an alternative option for screening COVID-19 in pregnant women if the CT chest is unavailable (9).

The laboratory result between both groups does not significantly differ in hemoglobin, leukocyte, thrombocyte, neutrophil, lymphocyte, and NLR value. Many studies and metaanalyses indicate that COVID-19 infection in an adult manifests as decreased leukocyte 
medRxiv preprint doi: https://doi.org/10.1101/2021.09.20.21263866; this version posted September 26, 2021. The copyright holder for this preprint (which was not certified by peer review) is the author/funder, who has granted medRxiv a license to display the preprint in It is made available under a CC-BY-NC-ND 4.0 International license .

(otherwise, in severe cases, leucocytosis), thrombocytopenia, decrease hemoglobin, neutrophilia, lymphopenia, and increase NLR value (21,23,31-34). Unfortunately, these changes are often found inconsistent in pregnant women. Pregnancy causes essential physiological changes, which lead to insignificant laboratory values changes in SARS-CoV-2 infection. For example, in the first-second trimester, leukocyte and lymphocyte values increase before finally decreasing in the third trimester (35). Neutrophilia can be found in the secondthird trimester caused by disruption of neutrophil apoptosis during pregnancy (36). The platelet value will also decrease in the third trimester, known as gestational thrombocytopenia (35). Study about laboratory changes in pregnancy is still minimal and provide inconsistent result. Liu et al. study shows a leukocytosis in half of the infected pregnant women; on the other hand, Chen et al. show that most pregnant women with COVID-19 show a decrease leukocyte value $(10,14)$. Neutrophil value is found to increase in pregnant women with COVID-19 in Liu et al. study, but Li et al. study shows an opposite result $(14,37)$.

NLR has been known as a consistent marker to predict the progression of COVID-19 disease. The increased level of NLR appears in a critically ill or severe COVID-19 case (18). A meta-analysis study, which includes 1579 participants, shows that NLR has excellent overall sensitivity, specificity, and AUC in predicting the severity of COVID-19 $(0.78,0.78$, dan 0.85$)$ (18). In this study, we use a high cut off value of NLR ( $>5.8)$ as a screening method of COVID19 in pregnancy. The result shows a lower AUC value compared to Li et al. study (0.561 vs 0.85) (18). Our study shows that NLR $>5.8$ has the highest diagnostic accuracy of other screening methods (DOR: 70.81). The sensitivity of NLR in our study is lower than the metaanalysis by Li et al. (41.38\% vs 78\%), but the specificity is similar (72 vs 78\%) (18). COVID19 in pregnancy causes an excessive inflammatory reaction, leading to cytokine storms and poor clinical outcomes. The presence of exaggerated inflammatory reaction and immune system suppression causes a progressively decreased lymphocyte number and increased 
medRxiv preprint doi: https://doi.org/10.1101/2021.09.20.21263866; this version posted September 26, 2021. The copyright holder for this preprint (which was not certified by peer review) is the author/funder, who has granted medRxiv a license to display the preprint in It is made available under a CC-BY-NC-ND 4.0 International license .

neutrophil. A neutrophil is a proinflammatory cell triggered by proinflammatory cytokine produced by SARS-CoV-2 such as IL-1, IL-6, and IL 8. On the other hand, this over inflammatory reaction will suppress lymphocyte production of CD4 and CD8 T cells $(38,39)$. Increased NLR level is one of the peripheral blood examinations which indicate an inflammatory reaction. Therefore pregnancy with COVID-19 will show an increased level of NLR. However, this is not found in our study; the mean NLR value between infected and noninfected pregnant women is not statistically different. The possible explanation for this finding may be related to the majority of our COVID-19 patient was mildly affected. Some studies have shown that the NLR value in severe COVID-19 patients was higher than the mild cases $(18,40,41)$.

Rapid antibody serological test from our study has a relatively low detection accuracy. The sensitivity of the rapid antibody test is moderate, but it has a low specificity. This finding is not following a study result in Italia (42). In a meta-analysis study which include 29.842 test, rapid antibody test with ELISA method show an overall good sensitivity and specificity (sens: 84.3\%, 95\% CI: 75.6-90.9\% \& specs: 99.7\%, 95\% CI: 99-100\%) (16). The rapid antibody test is not sufficient to be used as an early screening method of COVID-19 in pregnancy (42). With a specificity of $35 \%$, there is a possibility of $65 \%$ of pregnant women infected by SARS-CoV2 get a negative test result (false negative), so that this test will lead to many misdiagnoses. One of the possible explanations of the serological test's low accuracy in our study may be related to the timing of blood sampling. The majority of the test was performed in the acute early stage of the infection when the patient was admitted to the hospital. The sensitivity and specificity of antibody tests will be much higher in the third week of infection $(16,43)$. The rapid antibody test is more appropriate as an epidemiological surveillance tool of the disease in the general population and to diagnose the patients' immunity status (infection phase) (16,42-44). An antibody test can not be used as a single screening or diagnostic method for COVID-19 
medRxiv preprint doi: https://doi.org/10.1101/2021.09.20.21263866; this version posted September $26,2021$. The copyright holder for this preprint (which was not certified by peer review) is the author/funder, who has granted medRxiv a license to display the preprint in

It is made available under a CC-BY-NC-ND 4.0 International license.

infection and need a combination with clinical sign, laboratory, imaging, and RT=PCR test. The serological test can still be used in an algorithm of COVID-19 management to evaluate the recovery phase of mildly affected patients whose in self-isolation (surveillance). The negative IgM SARS-CoV-2 from the serological test may be used as an indicator of discontinuing the self-isolation periods (43). Recently serological antigen test of SARS-CoV-2 has been developed, which has a higher sensitivity, specificity, and accuracy than the serological antibody test in an early phase of infection (45).

This study's limitation is that the study population was all pregnant women with suspicion of COVID-19 infection. This matter will cause an unclear changes in clinical signs, laboratory, and additional examination because the control group was also a high-risk COVID19 population. Furthermore, we cannot evaluate this screening method's accuracy in the population of normal pregnant women (high and low risk) because of this inclusion criteria. We assume that the accuracy of this screening methods will be higher in the general population study.

In a low middle income countries where the RT-PCR test was limited, the goverment can used the combined screening methods consist of clinical sign and symptoms, serological test, chest x-ray, and NLR to classify pregnant women with high risk of COVID-19 infection. Pregnant women with at least one sign from screening method can be further diagnose with RT-PCR test. This approach can be used in a limited resources hospital or health services in low middle income countries.

\section{Conclusion}

This study found a moderate accuracy of a single parameter of the screening methods to detect COVID-19 in pregnant women. A combination of multiple parameters (such as clinical signs \& symptoms, serological test, chest x-ray, and NLR) could help classify pregnant women with 
medRxiv preprint doi: https://doi.org/10.1101/2021.09.20.21263866; this version posted September 26,2021 . The copyright holder for this preprint (which was not certified by peer review) is the author/funder, who has granted medRxiv a license to display the preprint in

It is made available under a CC-BY-NC-ND 4.0 International license .

a high risk of COVID-19 in the limited resources area. Pregnant women with positive signs from the screening methods can be further diagnosed with the RT-PCR test's gold standard. This practice will help to reduce the massive burden of RT-PCR examination in an area/country without sufficient resources.

\section{Acknowledgements}

We thank Prof. Nasronudin, MD, Ph.D., as the Director of Universitas Airlangga Hospital and all directors to support this study. We thank Brahmana Askandar Tjokroprawiro, MD, Ph.D. as the Head of Department Obstetrics \& Gynaecology Faculty of Medicine Universitas Airlangga and all the staff for their valuable input, comments, opinion, advice, and support in this study. We thank all the research team for their enormous effort in collecting data for this study. We thank all the patients for their participation in this study.

\section{Conflict of Interest}

The authors declare no conflict of interest in this study.

\section{Funding Statement}

This research received no spesific grant from any funding agency in the public, commercial, or not-for-profit sectors.

\section{References}

1. Worldometer. Coronavirus Cases Update [Internet]. 2021 [cited 2021 Feb 14]. Available from: https:/www.worldometers.info/coronavirus/

2. Satuan Tugas Penanganan Covid-19. Data Sebaran Situasi Virus Covid-19 di Dunia 
medRxiv preprint doi: https://doi.org/10.1101/2021.09.20.21263866; this version posted September $26,2021$. The copyright holder for this preprint (which was not certified by peer review) is the author/funder, who has granted medRxiv a license to display the preprint in It is made available under a CC-BY-NC-ND 4.0 International license .

dan Indonesia [Internet]. Satuan Tugas Penanganan Covid-19. 2020 [cited 2021 Feb 14]. Available from: https://covid19.go.id/

3. Sutton D, Fuchs K, D’Alton M, Goffman D. Universal screening for SARS-CoV-2 in women admitted for delivery. Vol. 382, New England Journal of Medicine. 2020. p. $2163-4$.

4. Poon LC, Yang H, Dumont S, Lee JCS, Copel JA, Danneels L, et al. ISUOG Interim Guidance on coronavirus disease 2019 (COVID-19) during pregnancy and puerperium: information for healthcare professionals - an update. Ultrasound Obstet Gynecol. 2020;55(6):848-62.

5. American Journal of Obstetrics and Gynecologist - Society for Maternal-Fetal Medicine ACOG-SMFM. Outpatient Assessment and Management for Pregnant Women With Suspected or Confirmed Novel Coronavirus ( COVID-19 ). Am J Obstet Gynecol. 2020;19(March):2020.

6. RCOG. Principles for the testing and triage of women seeking maternity care in hospital settings , during the COVID-19 pandemic. 2020.

7. Api O, Sen C, Debska M, Saccone G, D’Antonio F, Volpe N, et al. Clinical management of coronavirus disease 2019 (COVID-19) in pregnancy: Recommendations of WAPM-World Association of Perinatal Medicine. Journal of Perinatal Medicine. 2020.

8. Donders F, Lonnée-Hoffmann R, Tsiakalos A, Mendling W, De Oliveira JM, Judlin P, et al. ISIDOG recommendations concerning COVID-19 and pregnancy. Diagnostics. 2020;10(4):1-23.

9. Infeksi P, Reproduksi S, Obstetri P, Ginekologi DAN. Rekomendasi Penanganan Infeksi Virus Corona (COVID-19) Pada Maternal (Hamil, Bersalin, Dan Nifas) Edisi 1. 1st ed. POGI PISR, editor. Pokja Infeksi Saluran Reproduksi Perkumpulan Obstetri 
medRxiv preprint doi: https://doi.org/10.1101/2021.09.20.21263866; this version posted September 26, 2021. The copyright holder for this preprint (which was not certified by peer review) is the author/funder, who has granted medRxiv a license to display the preprint in It is made available under a CC-BY-NC-ND 4.0 International license .

Dan Ginekologi Indonesia. Jakarta: Perkumpulan Obstetri dan Ginekologi Indonesia; 2020.

10. Chen H, Guo J, Wang C, Luo F, Yu X, Zhang W. Clinical characteristics and intrauterine vertical transmission potential of COVID-19 infection in nine pregnant women : a retrospective review of medical records. Lancet. 2020;19.

11. Yang H, Wang C, Poon LC. Novel coronavirus infection and pregnancy. Ultrasound Obstet Gynecol. 2020;55(4):435-7.

12. Alberca RW, Pereira NZ, Oliveira LMDS, Gozzi-Silva SC, Sato MN. Pregnancy, Viral Infection, and COVID-19. Front Immunol. 2020;11(July):1-12.

13. Dana PM, Kolahdooz F, Sadoughi F, Moazzami B, Chaichian S, Asemi Z. COVID-19 and pregnancy: A Review of current knowledge. Infez Med. 2020;28:46-51.

14. Liu H, Liu F, Li J, Zhang T, Wang D. Clinical and CT imaging features of the COVID19 pneumonia: Focus on pregnant women and children. J Infect. 2020;e7-13.

15. Dashraath P, Lim LM, Li S, Biswas A, Choolani M. Coronavirus disease 2019 (COVID-19) pandemic and pregnancy. Am J Obstet Gynecol [Internet]. 2020;222(6):521-31. Available from: https://doi.org/10.1016/j.ajog.2020.03.021

16. Lisboa Bastos M, Tavaziva G, Abidi SK, Campbell JR, Haraoui LP, Johnston JC, et al. Diagnostic accuracy of serological tests for covid-19: Systematic review and metaanalysis. BMJ. 2020;370.

17. Qingdao Hightop Biotech Co. L. SARS-CoV-2 (COVID - 19) IgM/IgG Ab Rapid Test [Internet]. 2020. Available from:

http://www.hightopqd.com/en/productny.aspx?ProductsID=567\&oid=246\&CateId=73

18. Li X, Liu C, Mao Z, Xiao M, Wang L, Qi S, et al. Predictive values of neutrophil-tolymphocyte ratio on disease severity and mortality in COVID-19 patients: a systematic review and meta-analysis. Crit Care [Internet]. 2020;24(1):1-10. Available from: 
medRxiv preprint doi: https://doi.org/10.1101/2021.09.20.21263866; this version posted September $26,2021$. The copyright holder for this preprint (which was not certified by peer review) is the author/funder, who has granted medRxiv a license to display the preprint in It is made available under a CC-BY-NC-ND 4.0 International license .

https://doi.org/10.1186/s13054-020-03374-8

19. Breslin N, Baptiste C, Bennerman CG, Miller R, Martinez R, Bernstein K, et al. Coronavirus disease 2019 infection among asymptomatic and symptomatic pregnant women: two weeks of confirmed presentations to an affiliated pair of New York City hospitals. Am J Obstet Gynecol MFM. 2020;2:1-7.

20. Breslin N, Baptitste C, Gyamfi-Bannerman C, et. al. COVID-19 infection among asymptomatic and symptomatic pregnant women: Two weeks of confirmed presentations to an affiliated pair of New York City hospitals. J Chem Inf Model. 2019;

21. Allotey J, Stallings E, Bonet M, Yap M, Chatterjee S, Kew T, et al. Clinical manifestations, risk factors, and maternal and perinatal outcomes of coronavirus disease 2019 in pregnancy: Living systematic review and meta-analysis. BMJ. $2020 ; 370$.

22. Della Gatta AN, Rizzo R, Pilu G, Simonazzi G. Coronavirus disease 2019 during pregnancy: a systematic review of reported cases. Vol. 223, American Journal of Obstetrics and Gynecology. Mosby Inc.; 2020. p. 36-41.

23. Breslin N, Baptiste C, Miller R, Fuchs K, Goffman D, Gyamfi-Bannerman C, et al. Coronavirus disease 2019 in pregnancy: early lessons. Am J Obstet Gynecol MFM [Internet]. 2020;2(2):100111. Available from: https://doi.org/10.1016/j.ajogmf.2020.100111

24. Mullins E, Evans D, Viner RM, O’Brien P, Morris E. Coronavirus in pregnancy and delivery: rapid review. Ultrasound Obstet Gynecol. 2020;55(5):586-92.

25. Zaigham M, Andersson O. Maternal and perinatal outcomes with COVID-19: A systematic review of 108 pregnancies. Acta Obstet Gynecol Scand. 2020;99(7):823-9.

26. Chen H, Guo J, Wang C, Luo F, Yu X, Zhang W, et al. Clinical characteristics and intrauterine vertical transmission potential of COVID-19 infection in nine pregnant 
medRxiv preprint doi: https://doi.org/10.1101/2021.09.20.21263866; this version posted September 26, 2021. The copyright holder for this preprint (which was not certified by peer review) is the author/funder, who has granted medRxiv a license to display the preprint in It is made available under a CC-BY-NC-ND 4.0 International license .

women : a retrospective review of medical records. Lancet [Internet]. 2020;6736(20):1-7. Available from: http://dx.doi.org/10.1016/S0140-6736(20)30360-3

27. Meng X, Deng Y, Dai Z, Meng Z. COVID-19 and anosmia: A review based on up-todate knowledge Xiangming. Am J Otolaryngol. 2020;41(January):1-6.

28. Poon LC, Yang H, Lee JCS, Copel JA, Leung TY, Zhang Y, et al. ISUOG Interim Guidance on 2019 novel coronavirus infection during pregnancy and puerperium: information for healthcare professionals. Ultrasound Obstet Gynecol. 2020;55:700-8.

29. Ai T, Yang Z, Hou H, Zhan C, Chen C, Lv W, et al. Correlation of Chest CT and RTPCR Testing for Coronavirus Disease 2019 (COVID-19) in China: A Report of 1014 Cases. Radiology. 2020;

30. Mangal A, Kalia S, Rajgopal H, Rangarajan K, Namboodiri V, Banerjee S, et al. CovidAID: COVID-19 detection using chest X-ray. arXiv. 2020;1-10.

31. Khartabil TA, Russcher H, van der Ven A, de Rijke YB. A summary of the diagnostic and prognostic value of hemocytometry markers in COVID-19 patients. Crit Rev Clin Lab Sci [Internet]. 2020;57(6):415-31. Available from: https://doi.org/10.1080/10408363.2020.1774736

32. Park SE. Epidemiology, virology, and clinical features of severe acute respiratory syndrome coronavirus 2 (SARS-CoV-2; coronavirus disease-19). Pediatr Infect Vaccine. 2020;27(1):1-10.

33. World Health Organization (WHO). Clinical Management of Covid-19: Interim Guidance. 1st ed. WHO Library Catalog; 2020.

34. Tang Y, Schmitz JE, Persing DH, Stratton CW. Laboratory Diagnosis of COVID-19: Current Issues and Challenges. J Clin Microbiol. 2020;58(6):1-9.

35. Chandra S, Tripathi AK, Mishra S, Amzarul M, Vaish AK. Physiological changes in hematological parameters during pregnancy. Indian J Hematol Blood Transfus. 
medRxiv preprint doi: https://doi.org/10.1101/2021.09.20.21263866; this version posted September $26,2021$. The copyright holder for this preprint (which was not certified by peer review) is the author/funder, who has granted medRxiv a license to display the preprint in

2012;28(3):144-6.

36. Gatti L, Tenconi PM, Guarneri D, Bertulessi C, Ossola MW, Bosco P, et al.

Hemostatic parameters and platelet activation by flow-cytometry in normal pregnancy: a longitudinal study. Int J Clin Lab Res. 1994;

37. Li N, Han L, Peng M, Lv Y, Ouyang Y, Liu K, et al. Maternal and neonatal outcomes of pregnant women with COVID-19 pneumonia: A case-control study. medRxiv. 2020;

38. Mangalmurti N, Hunter CA. Cytokine Storms: Understanding COVID-19. Immunity. 2020;53(July):19-25.

39. Azkur AK, Akdis M, Azkur D, Sokolowska M, van de Veen W, Brüggen MC, et al. Immune response to SARS-CoV-2 and mechanisms of immunopathological changes in COVID-19. Vol. 75, Allergy: European Journal of Allergy and Clinical Immunology. 2020. 1564-1581 p.

40. Chan AS, Rout A. Use of Neutrophil-to-Lymphocyte and Platelet-to-Lymphocyte Ratios in COVID-19. J Clin Med Res. 2020;

41. Zeng F, Li L, Zeng J, Deng Y, Huang H, Chen B, et al. Can we predict the severity of coronavirus disease 2019 with a routine blood test? Polish Arch Intern Med. 2020;130(5):400-6.

42. Bruno R, Mondelli M, Brunetti E, Matteo A Di, Seminari E, Maiocchi L, et al. Performance of VivaDiag COVID-19 IgM/IgG Rapid Test is inadequate for diagnosis of COVID-19 in acute patients referring to emergency room department. J Med Virol. 2020;92(10):1724-7.

43. Zainol Rashid Z, Othman SN, Abdul Samat MN, Ali UK, Wong KK. Diagnostic performance of COVID-19 serology assays. Malays J Pathol. 2020;42(1):13-21.

44. La Marca A, Capuzzo M, Paglia T, Roli L, Trenti T, Nelson SM. Testing for SARSCoV-2 (COVID-19): a systematic review and clinical guide to molecular and 
medRxiv preprint doi: https://doi.org/10.1101/2021.09.20.21263866; this version posted September 26, 2021. The copyright holder for this preprint (which was not certified by peer review) is the author/funder, who has granted medRxiv a license to display the preprint in It is made available under a CC-BY-NC-ND 4.0 International license.

serological in-vitro diagnostic assays. Reprod Biomed Online. 2020;41(3):483-99.

45. Porte L, Legarraga P, Vollrath V, Aguilera X, Munita JM, Araos R, et al. Evaluation of a novel antigen-based rapid detection test for the diagnosis of SARS-CoV-2 in respiratory samples. Int J Infect Dis [Internet]. 2020 Oct;99(January):328-33. Available from: https://linkinghub.elsevier.com/retrieve/pii/S1201971220304057 
medRxiv preprint doi: https://doi.org/10.1101/2021.09.20.21263866; this version posted September 26, 2021. The copyright holder for this preprint (which was not certified by peer review) is the author/funder, who has granted medRxiv a license to display the preprint in It is made available under a CC-BY-NC-ND 4.0 International license.

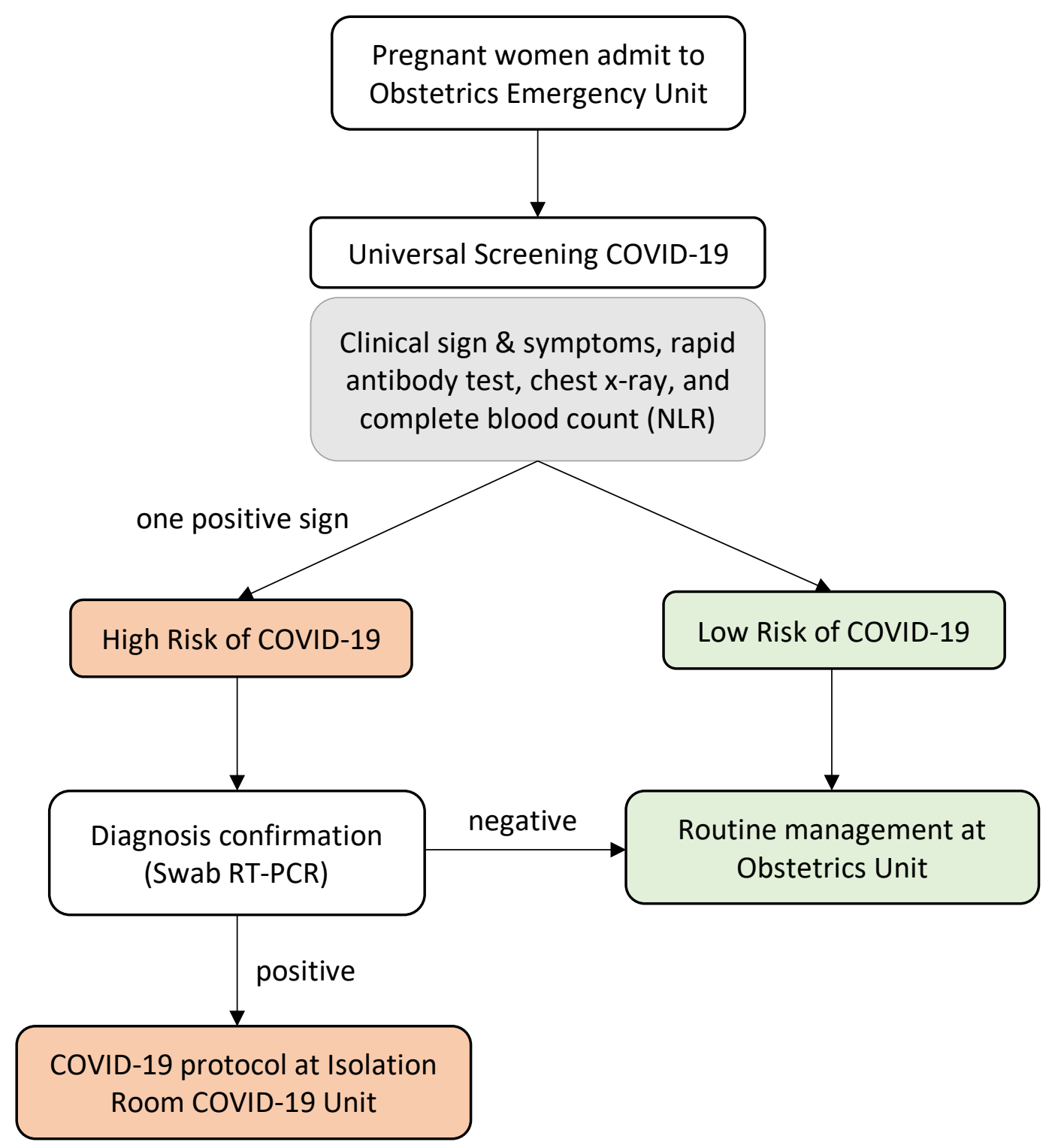

Figure 1. Algorithm of Screening of COVID-19 in Pregnant Women Admitted to Hospital.

All pregnant women admit to the hospital will be screened for the COVID-19 infection using the screening methods consist of: sign \& symptoms, rapid antibody test, chext x-ray and NLR $>$ 5.8. The presence of one positive sign indicate a high risk COVID-19 women, and need an additional diagnosis methods (swab RT-PCR). Women with positive molecular test were managed using a COVID-19 protocol at isolation room, while the negatives were routinely managed in obstetrics unit. 
medRxiv preprint doi: https://doi.org/10.1101/2021.09.20.21263866; this version posted September 26, 2021. The copyright holder for this preprint (which was not certified by peer review) is the author/funder, who has granted medRxiv a license to display the preprint in It is made available under a CC-BY-NC-ND 4.0 International license.

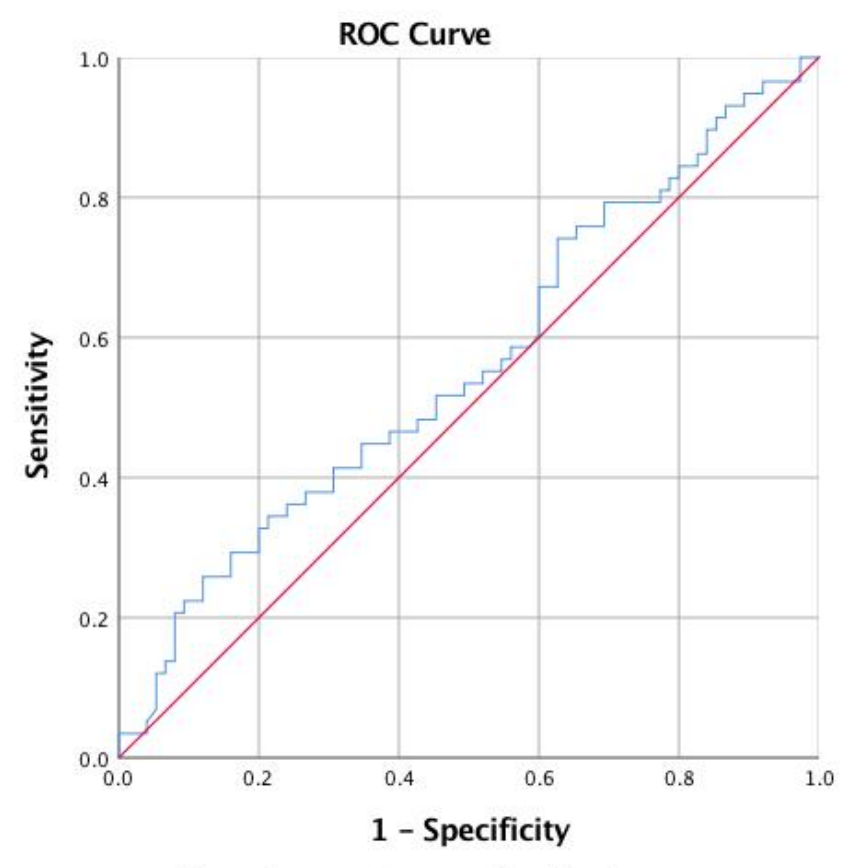

Diagonal segments are produced by ties.

Figure 2. ROC Curve of The NLR to predict COVID-19 infection in pregnant women.

NLR $>5.8$ has an AUC of 5.61 to predict the COVID-19 infection in pregnant women. The sensitivity and specificity from the ROC curve were only $37.9 \%$ and $30.7 \%$. 
medRxiv preprint doi: https://doi.org/10.1101/2021.09.20.21263866; this version posted September 26, 2021. The copyright holder for this preprint (which was not certified by peer review) is the author/funder, who has granted medRxiv a license to display the preprint in It is made available under a CC-BY-NC-ND 4.0 International license

Table 1. Screening and Diagnostic Test

\begin{tabular}{|c|c|c|c|}
\hline & $\begin{array}{l}\text { Non Covid } \\
n=79\end{array}$ & $\begin{array}{l}\text { Covid } \\
\mathrm{n}=62\end{array}$ & $P$-value \\
\hline Sign \& Symptoms & $19(24.1 \%)$ & $15(24.2 \%)$ & 0.984 \\
\hline Cough & $16(20.3 \%)$ & $12(19.4 \%)$ & 0.894 \\
\hline Fever & $5(6.3 \%)$ & $9(14.5 \%)$ & 0.107 \\
\hline Dyspneu & $6(7.6 \%)$ & $8(12.9 \%)$ & 0.295 \\
\hline Sore throat & $4(5.1 \%)$ & $3(4.8 \%)$ & 0.951 \\
\hline Myalgia & 0 & $1(1.6 \%)$ & 0.440 \\
\hline Nausea Vomiting & $2(2.5 \%)$ & $4(6.5 \%)$ & 0.405 \\
\hline \multicolumn{4}{|l|}{$\begin{array}{l}\text { Rapid antibody test } \\
\text { status }\end{array}$} \\
\hline Negative & $27(35.1 \%)$ & $15(27.3 \%)$ & 0.343 \\
\hline Positive & $50(64.9 \%)$ & $40(72.7 \%)$ & \\
\hline \multicolumn{4}{|l|}{$\begin{array}{l}\text { Rapid antibody test } \\
\text { status }\end{array}$} \\
\hline Negative & $27(34.2 \%)$ & $15(24.2 \%)$ & 0.245 \\
\hline Ig M positive & $10(12.7 \%)$ & $7(11.3 \%)$ & \\
\hline IgG positive & $16(20.3 \%)$ & $13(21 \%)$ & \\
\hline Ig M \& Ig G positive & $24(30.4 \%)$ & $20(32.3 \%)$ & \\
\hline Not examined & $2(2.5 \%)$ & $7(11.3 \%)$ & \\
\hline \multicolumn{4}{|l|}{ Chest X-ray } \\
\hline Normal & $47(59.5 \%)$ & $35(56.5 \%)$ & 0.142 \\
\hline Abnormal & $32(40.5 \%)$ & $24(38.7 \%)$ & \\
\hline Not performed & 0 & $3(4.8 \%)$ & \\
\hline \multicolumn{4}{|l|}{ NLR } \\
\hline NLR $<5.8$ & $54(72 \%)$ & $34(58.6 \%)$ & 0.106 \\
\hline $\mathrm{NLR} \geq 5.8$ & $21(28 \%)$ & $24(41.4 \%)$ & \\
\hline Hemoglobin & $11.34 \pm 1.48$ & $10.83 \pm 1.80$ & 0.072 \\
\hline Leucocyte $^{\mathrm{a}}$ & $11270 \pm 3500$ & $10552+5002$ & 0.327 \\
\hline Trombocyte $^{\mathrm{a}}$ & $279835 \pm 83053$ & $289306 \pm 80894$ & 0.504 \\
\hline Neutrophil & $76.1(9.8)$ & $76.6(11.75)$ & 0.217 \\
\hline
\end{tabular}


medRxiv preprint doi: https://doi.org/10.1101/2021.09.20.21263866; this version posted September 26, 2021. The copyright holder for this preprint (which was not certified by peer review) is the author/funder, who has granted medRxiv a license to display the preprint in It is made available under a CC-BY-NC-ND 4.0 International license.

\begin{tabular}{llll}
\hline Lymphocyte $^{\mathrm{s}}$ & $15.5(7.15)$ & $15.8(9.33)$ & 0.309 \\
\hline $\mathrm{NLR}^{\mathrm{B}}$ & $4.88(2.55)$ & $4.94(4.15)$ & 0.226 \\
\hline
\end{tabular}

This is the screening and diagnostic test comparison between Covid and non covid groups, consist of sign and symptoms, rapid antibody test status, laboratory result, and chest $\mathrm{x}$ ray. The categorical variables were analyzed using a Chi-square and Fischers exact test, while the numerical variables were analyzed using an independent t-test.

Note: ${ }^{a}$ indicates data with normal distribution, present with mean \pm SD. ${ }^{b}$ indicate data with abnormal distribution, present with median (interquartile range). 
medRxiv preprint doi: https://doi.org/10.1101/2021.09.20.21263866; this version posted September 26, 2021. The copyright holder for this preprint (which was not certified by peer review) is the author/funder, who has granted medRxiv a license to display the preprint in It is made available under a CC-BY-NC-ND 4.0 International license.

Table 2. Diagnostic accuracy of Clinical Sign \& Symptoms, Laboratory, Rapid Antibody test, and Chest X-ray

\begin{tabular}{|c|c|c|c|c|c|c|c|}
\hline & $\begin{array}{c}\text { Sensitivit } \\
\mathrm{y} \\
\%(95 \% \\
\mathrm{CI})\end{array}$ & $\begin{array}{c}\text { Spesificit } \\
\mathrm{y} \\
\%(95 \% \\
\mathrm{CI})\end{array}$ & $\begin{array}{c}\text { Positive } \\
\text { Likelihoo } \\
\text { d Ratio }\end{array}$ & $\begin{array}{c}\text { Negative } \\
\text { Likelihoo } \\
\text { d Ratio }\end{array}$ & $\begin{array}{c}\text { Positive } \\
\text { Predictiv } \\
\text { e Value } \\
\%(95 \% \\
\text { CI })\end{array}$ & $\begin{array}{c}\text { Negative } \\
\text { Predictiv } \\
\text { e Value } \\
\%(95 \% \\
\text { CI })\end{array}$ & $\begin{array}{c}\text { Accurac } \\
y \\
\%(95 \% \\
\text { CI) }\end{array}$ \\
\hline Cough & $\begin{array}{c}19.35 \\
(10.42- \\
31.37)\end{array}$ & $\begin{array}{c}79.75 \\
(69.20- \\
87.96)\end{array}$ & $\begin{array}{c}0.96 \\
(0.49- \\
1.87)\end{array}$ & $\begin{array}{c}1.01 \\
(0.86- \\
1.19)\end{array}$ & $\begin{array}{c}3.73 \\
(1.94- \\
7.05)\end{array}$ & $\begin{array}{c}96.06 \\
(95.38- \\
96.64)\end{array}$ & $\begin{array}{c}77.39 \\
(69.59- \\
84)\end{array}$ \\
\hline Fever & $\begin{array}{l}14.52 \\
(6.86- \\
25.78)\end{array}$ & $\begin{array}{r}93.67 \\
(85.84- \\
97.91)\end{array}$ & $\begin{array}{c}2.29 \\
(0.81- \\
6.50)\end{array}$ & $\begin{array}{c}0.91 \\
(0.81- \\
1.03)\end{array}$ & $\begin{array}{c}8.52 \\
(3.18- \\
20.87)\end{array}$ & $\begin{array}{c}96.43 \\
(96- \\
96.81)\end{array}$ & $\begin{array}{c}90.58 \\
(84.51- \\
94.85)\end{array}$ \\
\hline Dyspneu & $\begin{array}{c}12.9 \\
(5.74- \\
23.85)\end{array}$ & $\begin{array}{l}92.41 \\
(84.2- \\
97.16)\end{array}$ & $\begin{array}{c}1.7 \\
(0.62- \\
4.64)\end{array}$ & $\begin{array}{c}0.94 \\
(0.84- \\
1.06)\end{array}$ & $\begin{array}{c}6.45 \\
(2.46- \\
15.85)\end{array}$ & $\begin{array}{c}96.32 \\
(95.85- \\
96.70)\end{array}$ & $\begin{array}{c}89.3 \\
(82.99- \\
93.88)\end{array}$ \\
\hline $\begin{array}{l}\text { Sore } \\
\text { throat }\end{array}$ & $\begin{array}{c}4.84 \\
(1.01- \\
13.5)\end{array}$ & $\begin{array}{r}94.94 \\
(87.54- \\
98.60)\end{array}$ & $\begin{array}{c}0.96 \\
(0.22- \\
4.11)\end{array}$ & $\begin{array}{c}1.00 \\
(0.93- \\
1.08)\end{array}$ & $\begin{array}{c}3.73 \\
(0.89- \\
14.30)\end{array}$ & $\begin{array}{l}96.09 \\
(95.8- \\
96.37)\end{array}$ & $\begin{array}{c}91.42 \\
(85.52- \\
95.48)\end{array}$ \\
\hline $\begin{array}{c}\text { Nausea } \\
\text { vomittin } \\
\mathrm{g}\end{array}$ & $\begin{array}{c}6.45 \\
(1.79- \\
15.7)\end{array}$ & $\begin{array}{l}97.47 \\
(91.15- \\
99.69)\end{array}$ & $\begin{array}{l}2.55 \\
(0.48- \\
13.46)\end{array}$ & $\begin{array}{c}0.96 \\
(0.89- \\
1.03)\end{array}$ & $\begin{array}{c}9.37 \\
(1.92- \\
35.33)\end{array}$ & $\begin{array}{c}96.25 \\
(95.97- \\
96.51)\end{array}$ & $\begin{array}{r}93.92 \\
(88.61- \\
97.25)\end{array}$ \\
\hline $\begin{array}{l}\text { Combine } \\
\text { d Sign \& } \\
\text { symptom } \\
\text { s }\end{array}$ & $\begin{array}{c}24.19 \\
(14.22- \\
36.74)\end{array}$ & $\begin{array}{r}75.95 \\
(65.02- \\
84.86)\end{array}$ & $\begin{array}{c}1.01 \\
(0.56- \\
1.81)\end{array}$ & $\begin{array}{c}1.00 \\
(0.83- \\
1.20)\end{array}$ & $\begin{array}{c}3.92 \\
(2.21- \\
6.86)\end{array}$ & $\begin{array}{c}96.11 \\
(95.34- \\
96.75)\end{array}$ & $\begin{array}{c}65.87 \\
(65.87- \\
80.96)\end{array}$ \\
\hline $\begin{array}{c}\text { Rapid } \\
\text { antibody } \\
\text { test }\end{array}$ & $\begin{array}{c}72.73 \\
(59.04- \\
83.86)\end{array}$ & $\begin{array}{c}35.06 \\
(24.53- \\
46.78)\end{array}$ & $\begin{array}{c}1.12 \\
(0.89- \\
1.41)\end{array}$ & $\begin{array}{c}0.78 \\
(0.46- \\
1.32)\end{array}$ & $\begin{array}{c}4.35 \\
(3.48- \\
5.41)\end{array}$ & $\begin{array}{c}96.94 \\
(94.92- \\
98.17)\end{array}$ & $\begin{array}{c}36.53 \\
(28.33- \\
45.36)\end{array}$ \\
\hline $\begin{array}{c}\text { Chest X- } \\
\text { Ray }\end{array}$ & $\begin{array}{c}40.68 \\
(28.07- \\
54.25)\end{array}$ & $\begin{array}{r}59.45 \\
(47.85- \\
70.40)\end{array}$ & $\begin{array}{c}1.00 \\
(0.67- \\
1.51)\end{array}$ & $\begin{array}{c}1.00 \\
(0.75- \\
1.32)\end{array}$ & $\begin{array}{c}3.92 \\
(2.64- \\
5.77)\end{array}$ & $\begin{array}{c}96.11 \\
(94.92- \\
97.03)\end{array}$ & $\begin{array}{c}58.76 \\
(50.07- \\
67.07)\end{array}$ \\
\hline $\begin{array}{c}\mathrm{NLR} \geq \\
5.8\end{array}$ & $\begin{array}{c}41.38 \\
(28.60- \\
55.07)\end{array}$ & $\begin{array}{r}72.00 \\
(60.44- \\
81.76)\end{array}$ & $\begin{array}{c}1.48 \\
(0.92- \\
2.38)\end{array}$ & $\begin{array}{c}0.81 \\
(0.63- \\
1.05)\end{array}$ & $\begin{array}{c}5.66 \\
(3.60- \\
8.80)\end{array}$ & $\begin{array}{c}96.80 \\
(95.90- \\
97.51)\end{array}$ & $\begin{array}{c}70.81 \\
(62.30- \\
78.36)\end{array}$ \\
\hline
\end{tabular}

This is the diagnostic accuracy parameter for each individual variables to detect covid-19, consists of: sign \& symptoms, rapid antibody test, chest x-ray, and NLR. All parameter were performed using diagnostic accuracy test to evalute the sensitivity, spesificity, positive likelihood ratio, negative likelihood ratio, positive predictive value, negative predictive value and diagnostic accuracy. 